\title{
UBE3Aren substratuak identifikatzen Angelman sindromearen ingurukoak argitzeko
} \section{(Identifying UBE3A substrates to shed light into Angelman syndrome)}

\author{
Juanma Ramirez ${ }^{1}$, Benoit Lectez ${ }^{1}$, Nerea Osinalde ${ }^{2}$, Nagore Elu ${ }^{1}$, Ugo Mayor*1,3 \\ ${ }^{1}$ Biokimika eta Biologia Molekularra Saila, Zientzia eta Teknologia Fakultatea, \\ Leioa (UPV/EHU) \\ ${ }^{2}$ Biokimika eta Biologia Molekularra Saila, Farmazia Fakultatea, \\ Gasteiz (UPV/EHU)
}

${ }^{3}$ Ikerbasque Ikerkuntzarako Euskal Fundazioa, Bilbo

\begin{abstract}
LABURPENA: Angelman sindromea neurogarapenezko gaixotasun bakana da, eta, arrazoiak arrazoi, neuronetan amarengandik jasotako UBE3A genearen kopia adierazten ez duten gizabanakoek pairatzen dute. UBE3Ak E3 ubikuitina ligasa entzima bat kodetzen du, zeina, E1 eta E2 entzimekin elkarlanean, itu-proteinei ubikuitina deritzon molekula txiki bat itsasteaz arduratzen den. Proteina bati ubikuitina gehitzeak berebiziko eragina izan dezake beraren patuan; izan ere, besteak beste, proteinen biziraupena, zelula barruko kokapena edota proteinen arteko elkarrekintzak baldintzatu ditzake. Beraz, ubikuitinazio-prozesuaren garrantzia ikusirik, eta UBE3Aren funtzioa zein den aintzat hartuta, pentsatzekoa da UBE3Aren faltan beraren itu-proteinen ubikuitinazio-maila gutxitua egongo dela, eta horrek eragin zuzena izango duela ez soilik proteinetan, baita zelularen funtzionamenduan ere. Angelman sindromea pairatzen dutenen zelula mailako kalteen jatorria ulertzeko, ezinbestekoa da UBE3Ak kodetzen duen E3 ubikuitina ligasaren itu-proteinak edo substratuak zeintzuk diren jakitea. Hori argitze aldera, UBE3A gainadierazten duten eta gainadierazten ez duten Drosophila eulietan ubikuitinatuta dauden proteinak aztertu eta konparatu ditugu. Ubikuitinatutako proteinak arrantzatzeko, gure laborategian garatutako BioUb estrategia erabili dugu, eta, ondoren, horiek identifikatzeko eta kuantifikatzeko, masa-espektrometria (MS) erabili dugu. Identifikatutako ehunka proteinetatik, 79k betetzen dituzte UBE3Aren substratu izateko irizpideak. Horien artean dago Rnp10, aurretiaz UBE3Aren itu-proteina gisa deskribatu den proteina. Horrez gain, Rngo deituriko proteinak piztu zuen gure arreta, eta, biologia molekularreko teknika osagarriak erabiliz, MS bidezko emaitzak berretsi ditugu. Gainera, giza zelulak erabiliz, Rngo-ren homologoa den DDI1 ere UBE3Aren substratua dela frogatu dugu. Etorkizunean, gure helburu nagusiak hiru dira: (i) MS bidez identifikatutako UBE3Aren substratu-izangai gehiago egiaztatzea, (ii) proteina horiek gizakietan ere UBE3Aren substratuak direnentz frogatzea, eta (iii) UBE3Aren substratuek zelula mailan betetzen dituzten funtzioak aztertzea.
\end{abstract}

HITZ GAKOAK: Angelman sindromea, UBE3A, ubikuitina, substratua.

ABSTRACT: Angelman syndrome (AS) is a rare neurodevelopmental disease that results from loss of function of the maternal UBE3A gene. UBE3A codes for an E3 ubiquitin ligase, that coordinately with E1 and E2 enzymes, attaches ubiquitin to proteins. Ubiquitination plays a key role in the fate of proteins. For instance, it can target a protein for degradation, relocate the protein within the cell or determine protein-protein interactions. Therefore, considering the relevance of ubiquitination, and the function of UBE3A, it could be anticipated that in the absence of UBE3A, the ubiquitination pattern of its substrates will be inadequate, thus affecting not only proteins, but also cell physiology. Consequently, to understand the aetiology of the neuronal defects in AS patients, it is mandatory to know which the substrates of UBE3A are. With that aim, we compared the proteins that are ubiquitinated in Drosophila flies overexpressing and not overexpressing UBE3A. Briefly, we combined the BioUb strategy developed in our lab with mass spectrometry, to isolate and detect ubiquitinated proteins, respectively. From the hundreds of proteins detected, 79 fulfilled the criteria to be considered as putative UBE3A substrate. One of those proteins was Rpn10, previously reported to be a UBE3A substrate. Additionally, we confirmed MS results indicating that Rngo might be a UBE3A substrate. Moreover, using human cells we proved that human Rngo homolog DDII is also a UBE3A substrate. Now we plan to (i) validate more UBE3A substrates, (ii) check whether those proteins are also substrates in human, and (iii) characterize their biological role.

KEYWORDS: Angelman syndrome, Ube3a, ubiquitin, substrate.

* Harremanetan jartzeko / Corresponding author: Ugo Mayor, Biokimika eta Biologia Molekularra saila. Zientzia eta Teknologia Fakultatea. (UPV/EHU), Sarriena auzoa, zg, (48940, Leioa-Bizkaia). - ugo.mayor@ehu.eus - https://orcid.org/0000-00032812-8287.

Nola aipatu / How to cite: Ramirez, Juanma; Lectez, Benoit; Osinalde, Nerea; Elu, Nagore; Mayor, Ugo (2019). "UBE3Aren substratuak identifikatzen Angelman sindromearen ingurukoak argitzeko»; Ekaia, 36, 2019, 151-161. (https://doi.org/10.1387/ekaia.20822)

Jasoa: 03 maiatza, 2019; Onartua: 10 uztaila, 2019

ISSN 0214-9001 - eISSN 2444-3255 / ㄷ 2019 UPV/EHU

(c) (i) (-) Obra hau Creative Commons Atribución 4.0 Internacional-en

(c) ${ }_{\text {BY }}$ SA lizentziapean dago 
Juanma Ramirez, Benoit Lectez, Nerea Osinalde, Nagore Elu, Ugo Mayor

\section{SARRERA}

Angelman sindromea (AS) neuroendekapenezko gaixotasun bakana da, jaiotzen diren 15.000 haurretatik, gutxi gorabehera, bati eragiten diona. Gaitza pairatzen dutenek hitz egiteko zailtasunak, muskuluen mugimenduan koordinazio falta, epilepsia krisiak eta, maiz, lo-asaldurak izan ohi dituzte, besteak beste. Hala ere, etengabeko irribarrea da AS gaixoen ezaugarri bereizgarriena [1].

AS gaixotasun genetikoa da, UBE3A deritzon genearen galerak eragiten duena. Arrazoiak arrazoi, amarengandik jasotako UBE3A genearen kopia neuronetan oker adierazten dutenek edo, besterik gabe, adierazten ez dutenek garatzen dute AS [2, 3]. UBE3A geneak E3 ubikuitina ligasa bat kodetzen du. Oro har, E3 ubikuitina ligasak, E1 eta E2 entzimekin elkarlanean, zelulako proteinei ubikuitina deritzon molekula txiki bat (edo gehiago) gehitzeaz arduratzen dira (1. irudia) [4].

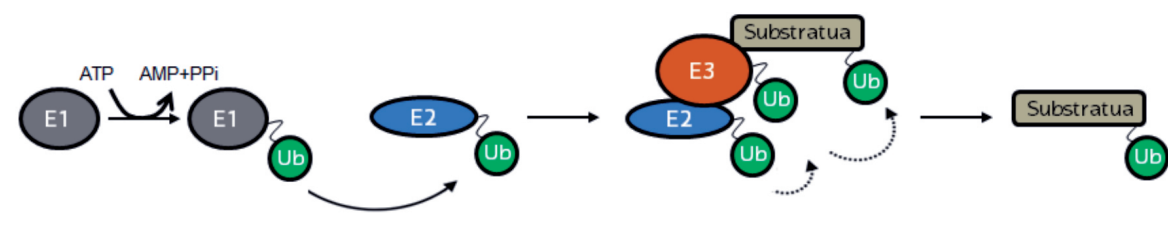

1.irudia. Proteinen ubikuitinazio-prozesua. Hasteko, E1 entzimak ubikuitina aktibatzen du (Ub, berdez, aktibatutako ubikuitina). Ondoren, aktibatutako ubikuitina E2 entzimari lotzen zaio, eta, azkenik, E3 ubikuitina, ligasaren laguntzarekin, ubikuitina itu-proteinari edo substratuari atxikitzen zaio.

Ubikuitina 76 aminoazidoko proteina txiki bat da, organismo eukariotikoen zelula guztietan adierazten dena. Ebolutiboki oso kontserbatua dago, eta, adibidez, gizakiaren eta legamiaren ubikuitinek sekuentziaren \% 96 partekatzen dute. Ubikuitinaren ezaugarri bereizgarrien artean, nabarmentzekoa da 7 lisina eta, karboxilo-muturrean, bi glizina aminoazido (diGly) dituela. Hain zuzen ere, ubikuitinaren azken glizina izaten da itu-proteinaren lisina batekin erreakzionatzen duena. Horrez gain, ubikuitinak berak hainbat lisina dituenez, izaera ezberdinetako ubikuitina kateak eratu daitezke.

Proteina bati ubikuitina gehitzeak askotariko efektuak eragin ditzake. Proteina ubikuitinatzearen ondorioz, beraren kokapena alda daiteke zelula barruan. Adibidez, argi ultramorearekin irradiatutako zeluletan DNA kaltetzen denean, nukleoan aritzen den Tax proteina ubikuitinatu egiten da; zehazki, 280. eta 284. posizioko lisinetan (K280 eta K284). Ondorioz, ubikuitinatutako Tax nukleotik zitoplasmara kanporatzen da, eta funtzional izateari uzten dio [5]. Beste kasu batzuetan, ubikuitinatzen diren proteinak proteasomara edo lisosomara bideratzen dira, bertan degradatuak izan dai- 
tezen. Halaxe gertatzen da, besteak beste, eIF4E-ren K159 [6], D1 ziklinaren K269 [7] eta MyoD-ren K133 ubikuitinatzean [8]. Bestalde, nabarmentzekoa da seinalizazio-bidezidor ugari ere ubikuitinazio bidez erregulatzen direla [9-11].

Arestian aipatutako adibide horiek guztiak kontutan izanda, ez da harritzekoa, proteinak ubikuitinatzeaz arduratzen den entzima baten gabeziak Angelman sindromea bezalako gaixotasun larri bat eragitea. Izan ere, E3 entzima bakar batek proteina askoren gain eragiten du. Hori horrela izanik, UBE3Aren itu-proteinen, hots, UBE3Ak ubikuitinatzen dituen proteinen, identitatea ezagutzea ezinbestekoa da gaixotasunarekin erlazionatutako akats neuronalen jatorria ulertzeko. Hori dela eta, Angelman sindromean inplikatutako molekulak eta molekula mailako mekanismoak ezagutzeko asmoz, UBE3Aren itu-proteinak izan da gure ikerketaren helburu nagusia.

\section{(bioUb) ${ }_{6}$-BirA konstruktua}
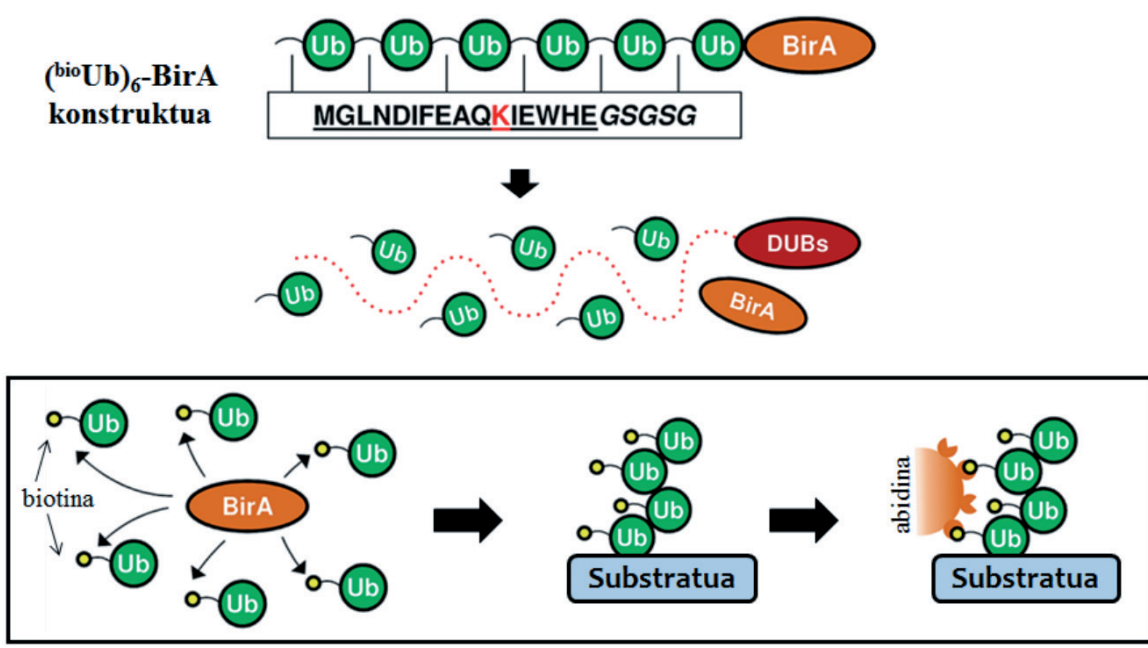

2. irudia. BioUb estrategiaren eskema orokorra. Zelulako DUBek bio ${ }^{\text {bb }} b_{6}-\mathrm{BirA}$ konstruktua prozesatzen dute, eta, ondorioz, ubikuitinak eta BirA aske geratzen dira. BirAk ubikuitinak biotinilatzen ditu, eta, ondoren, zelulako E1-E2-E3 entzimek biotinilatutako ubikuitina erabiliko dute substratuei gehitzeko. Azkenik, abidinazko bolatxoak erabiliz, biotinilatutako, hots, ubikuitinatutako, substratuak arrantzatzen dira.

Oro har, proteina baten kopia guztietatik, gutxieneko bat egoten da ubikuitinatuta. Horrenbestez, ubikuitinatutako frakzioa detektatu ahal izateko, aldez aurretik aberastu, hots, arrantzatu egin behar da. Eginkizun horretarako, azken hamarkadan, antigorputz bereziak erabili izan dira; hain zuzen, proteinei lotutako ubikuitina kentzean horrek uzten duen diGly marka 
Juanma Ramirez, Benoit Lectez, Nerea Osinalde, Nagore Elu, Ugo Mayor

ezagutzen dutenak $[12,13]$. Alabaina, Nedd8 edo ISG15 lotuta daukaten proteinak ebakitzean ere marka bera sortzen da; beraz, antigorputz horiek ubikuitinatutako proteinak ez ezik, beste eraldaketa mota batzuk dituzten proteinak ere arrantzatu ditzakete [14]. Gure ikerketa taldean, espezifikoki ubikuitinatutako proteinak arrantzatzeko teknika berri bat garatu genuen, BioUb izenekoa [15] (2. irudia). Teknika horri esker, arrantzatutako proteinen jarraipena ere egin daiteke, bai MSren bidez, baita Western plapaketa bidez ere. Eta, hori gutxi balitz, diGly antigorputzekin alderatuz, BioUb teknika erabiliz esperimentutik esperimentura lortzen den errepikagarritasuna oso altua da.

BioUb estrategian, lehenik eta behin ( $\left.{ }^{\text {bio }} \mathrm{Ub}\right)_{6}$-BirA konstruktua gainadierazten da zeluletan (2. irudia). (bio Ub) ${ }_{6}$-BirA konstruktuak 2 osagai nagusi ditu: alde batetik, elkarren segidan dauden 6 ubikuitina, eta, bestetik, bakterioen BirA entzima. Konstruktua gainadierazten denean, zelulako deubikuitinasek, hots, DUBek, konstruktua mozten dute, ubikuitinak eta BirA entzima aske utziz. Ubikuitina horietako bakoitzak 16 aminoazidoko sekuentzia bat dauka, zeina BirAk ezagutzen duen (2. irudian azpimarratutako sekuentzia). Ondorioz, BirAk sekuentzia horretako lisinan (K, gorriz) biotina gehitzen du, eta ubikuitinak biotinilatuta geratzen dira. Ubikuitina horiek zelulako ubikuitinen pare funtzionatzen dute. Hortaz, E1-E2-E3 entzimek biotinilatutako ubikuitinak erabiltzen dituzte beren itu-proteinei itsasteko. Laburki esanda, teknika honekin ubikuitinatutako proteinak biotinaz ere markatzen dira. Ondoren, biotinaren eta abidinaren arteko elkarrekintza sendoaz baliatuz, biotinilatutako, eta beraz ubikuitinatutako, proteinak arrantzatu daitezke. Gainera, biotinaren eta abidinaren arteko elkarrekintza hain da sendoa, ezen, arrantzaren ostean, garbiketak baldintza gogorretan egitea posible den. Horri esker, elkarrekintza ez-espezifikoak, alegia, faltsu positiboak, baztertzen dira.

Arestian esan bezala, UBE3A bere itu-proteinei ubikuitina itsasteaz arduratzen da. Beraz, aurreikus liteke, zeluletan UBE3A gainadieraziz gero, beraren itu-proteinen ubikuitinazio-maila ohikoa baino handiagoa izango dela (3. irudia).

Hori aintzat hartuta, BioUb teknika erabiliz, UBE3A gainadierazten duten $\left(\mathrm{Bio}^{\mathrm{UBE} 3 \mathrm{~A}}\right)$, baita UBE3A maila normala duten $\left(\mathrm{Bio}^{\mathrm{Ub}}\right)$ eulien neuronetatik ere, ubikuitinatutako proteinak isolatu ditugu. Isolatutako proteinak prozesatu ondoren, masa espektrometriaren (MS) bidez identifikatu eta kuantifikatu ditugu (3. irudia). Erabilitako prozedurari esker, ordura arte ezagutzen ez ziren UBE3Aren zenbait itu-proteina berri aurkitu ditugu [16]. 


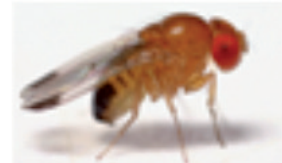

Bioub

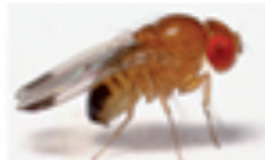

Bio Uet3a

(Bioub gainadierazi)

(BioUb + UBE3A gainadierazi)

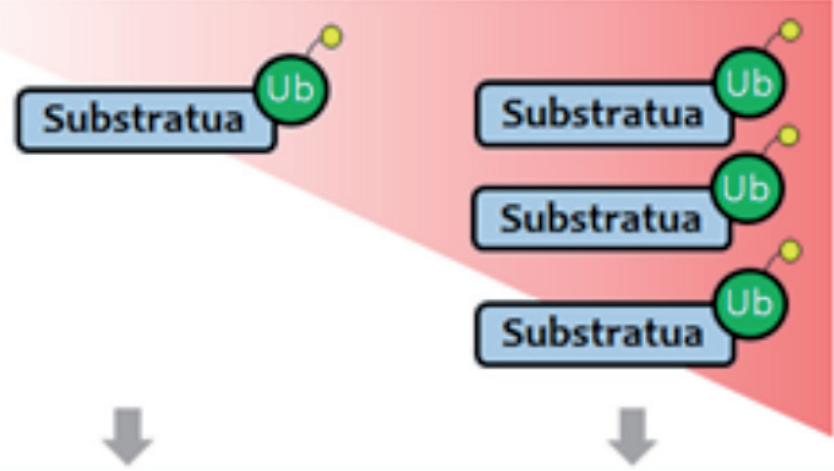

BioUb: Ubikuitinatutako proteinen arrantza

Arrantzatutako proteinen prozesamendua

\section{MS: proteinen identifikazioa \& kuantifikazioa}

3. irudia. UBE3Aren substratuak aurkitzeko erabilitako prozeduraren eskema. BioUb $\left(\mathrm{Bio}^{\mathrm{Ub}}\right)$ eta, BioUb-z gain, UBE3A $\left(\mathrm{Bio}^{\mathrm{UBE} 3 \mathrm{~A}}\right)$ gainadierazten dituzten eulietatik, ubikuitinatutako proteinak arrantzatzen dira BioUb sistema erabiliz. Ondoren, proteinak prozesatzen dira MSren bidez, identifikatzeko eta kuantifikatzeko. Bio ${ }^{\text {UBE3A }}$ egoeran $\mathrm{Bio}^{\mathrm{Ub}}$ egoeran baino ugariagoak diren proteinak izango dira UBE3Aren substratu izateko aukera daukatenak.

\section{EMAITZAK}

UBE3Aren substratuak aurkitzeko, 3. irudian adierazitako prozedura erabili dugu. Laburki, BioUb eta MS uztartu ditugu soilik BioUb eta, BioUb-z gain, UBE3A gainadierazten dituzten eulien ubikuitomak, hots, ubikuitinatutako proteinen populazioak, aztertu eta konparatzeko. Hasteko, bi euli moten buruetatik proteinak erauzi, eta, gure laborategian garatutako BioUb teknika erabilita, ubikuitinatutako proteinak arrantzatu genituen. Ja- 
Juanma Ramirez, Benoit Lectez, Nerea Osinalde, Nagore Elu, Ugo Mayor

rraian, arrantzatutako proteinak, hots, ubikuitinatutakoak, poliakrilamidazko gel batean banatu genituen, proteinak tamainaren arabera bana zitezen. Gela koloratzaile batekin tindatu ostean, gela hiru zatitan moztu genuen. Gel zati bakoitza zati are txikiagotan moztu genuen, eta, ondoren, bertako proteinak digeritu genituen tripsina izeneko entzima erabiliz. Proteinak zatitzen direnean peptido izeneko kate motzak sortzen dira, eta horiek geletik erauz daitezke. Azkenik, peptido horiek masa-espektrometroan analizatu genituen, jatorrizko proteinak zeintzuk diren jakiteko [17]. Nabarmendu beharra dago, euli mota bakoitzarekin hiru aldiz errepikatu genuela prozedura bera.

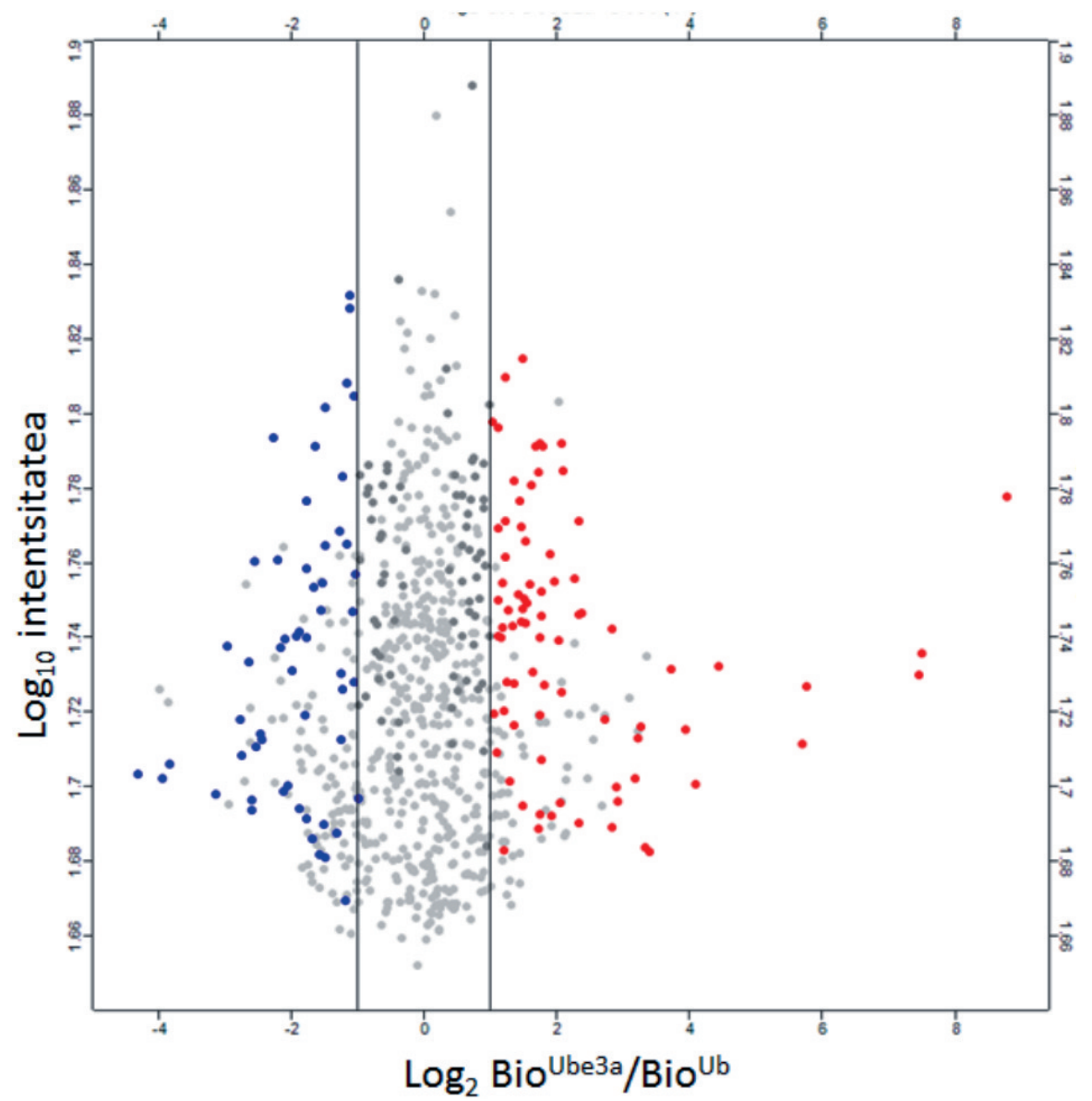

4. irudia. Proteomika diferentzialeko emaitzak. Gorriz, $\mathrm{Bio}^{\mathrm{UBE} 3 \mathrm{~A}} / \mathrm{Bio}^{\mathrm{Ub}}>2$ (hots, $\log _{2}$ ratioa $>1$ ) eta Student t-testaren p-balioa $<0.05$. Urdinez, Bio ${ }^{\text {Ube3a/ }}$ $\mathrm{Bio}^{\mathrm{Ub}}<0.05$ (hots, $\log _{2}$ ratioa $>-1$ ) eta Student t-testaren p-balioa $<0.05$. Gris argiaz, Student t-testaren p-balioa $>0.05$. Gainerakoak, hots, gris ilunak, Bio ${ }^{\text {UBE3A/ }}$ $\mathrm{Bio}^{\mathrm{Ub}}$ 0.5-2 bitartean daukatenak, nahiz eta Student t-testaren p-balioa $<0.05$ izan. 
Masa-espektrometria baliagarria da bi laginetako edo gehiagotako proteinen ugaritasuna konparatzeko [18]. Hori da, hain zuzen ere, guk egin duguna UBE3Aren itu-proteinak kuantifikatzeko. Bio ${ }^{\mathrm{Ub}}$ eta Bio ${ }^{\text {UBE3A }}$ laginetan identifikatutako proteina bakoitzerako masa-espektrometroak neurtutako peptidoen intentsitateak konparatu ditugu. Orotara, 751 proteina identifikatu eta kuantifikatu ditugu $\mathrm{Bio}^{\mathrm{Ub}}$ eta $\mathrm{Bio}^{\mathrm{UBE} 3 \mathrm{~A}}$ eulietan. 4. irudian ikus daitekeen bezala, atzemandako proteina gehienen ugaritasuna beretsua da bi euli motetan $\left(\mathrm{Bio}^{\mathrm{UBE} 3 \mathrm{~A}} / \mathrm{Bio}^{\mathrm{Ub}}\right.$ ratioa $\sim 1$, hots, $\log _{2} \mathrm{Bio}^{\mathrm{UBE} 3 \mathrm{~A}} / \mathrm{Bio}^{\mathrm{Ub}} \mathrm{ra}-$ tioa $\sim 0$ ). Bi egoeretatik arrantzatutako proteinen ugaritasuna alderatzeaz gain, diferentzia horiek estatistikoki adierazgarriak diren ere kalkulatu dugu, Student t-test delako estatistikoa erabiliz. Proteina bat UBE3Aren itu-proteinatzat edo substratutzat hartua izateko, 2 baldintza bete behar ditu: alde batetik, proteinaren intentsitatea $\mathrm{Bio}^{\mathrm{UBE} 3 \mathrm{~A}} / \mathrm{Bio}^{\mathrm{Ub}}>2$ izatea

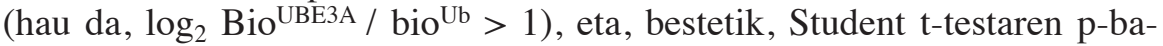
lioa $<0.05$ izatea. Atzemandako 751 proteinetatik $79 \mathrm{k}$ betetzen dituzte bi baldintza horiek (4. irudian gorriz markatutakoak).

UBE3Aren substratuak izan litezkeen horien artean (4. irudian, puntu gorriak), askok proteinen homeostasian hartzen dute parte (1. taula): autofagiarekin erlazionatutako $\operatorname{Atg} 8$ a eta $\operatorname{Ref}(2) \mathrm{P}[19,20]$, proteasomako hainbat azpiunitate (Pros $\alpha 1$, Pros $\alpha 3$, Pros4, Pros7, Rpt2, Rpt4, Rpn2, Rpn3 eta Rpn8) [21], proteasoma aktibatzen duen REG proteina [22], bai eta proteinak proteasomara bidaltzeaz arduratzen diren bi bitartekari ere, hain zuzen Rngo eta Rpn10 [23, 24].

1. taula. Proteinen homeostasiarekin zerikusia duten UBE3Aren substratu potentzialak. Proteina bakoitzerako kalkulatu den Bio ${ }^{\mathrm{UBE} 3 \mathrm{~A} /}$ $\mathrm{Bio}^{\mathrm{Ub}}$ ratioa nahiz Student $t$-testaren $p$-balio estatistikoa adierazten dira.

\begin{tabular}{lcc}
\hline \multicolumn{1}{c}{ Proteina } & Bio $^{\text {UBE3A }} /$ Bio $^{\text {Ub }}$ ratioa & Student t-testaren p-balioa \\
\hline Atg8 & 2,8 & 0,031 \\
Ref(2)P & 3,43 & 0,0003 \\
Prosalpha1 & 4,05 & 0,00023 \\
Prosalpha3 & 4,18 & 0,048 \\
Prosalpha4 & 3,4 & 0,0025 \\
Prosalpha7 & 51,7 & $1,21 \mathrm{E}-05$ \\
Rpt2 & 2,5 & 0,034 \\
Rpt4 & 2,5 & 0,0034 \\
Rpn2 & 2 & 0,021 \\
Rpn8 & 2,1 & 0,047 \\
REG & 2,35 & 0,005 \\
Rpn10 & 2,75 & 0,29 \\
Rngo & 5 & 0,00015 \\
\hline
\end{tabular}


Juanma Ramirez, Benoit Lectez, Nerea Osinalde, Nagore Elu, Ugo Mayor

Aipatu beharra dago duela gutxi neuronen zelula-hazkuntzak erabilita aurkitu zela lehenengoz Rpn10 proteina UBE3Aren substratua dela [25]. Beraz, gure esperimentuan ere Rpn10 detektatzeak erakusten du erabilitako estrategia egokia dela UBE3Aren itu-proteinak detektatzeko.

Arestian aipatutako proteina horietatik guztietatik, Rngo da bereziki gure interesa piztu zuena. Horregatik, MSren bidez lortutako emaitza Western plapaketa bidez berresten saiatu ginen, baita lortu ere. Beraz, gure lanak lehen aldiz frogatu du Rngo UBE3Aren substratua dela eulietan [16].

Eulietan behatutako hori bera gizakiotan gertatzen denetz frogatzea izan zen gure hurrengo helburua. Ugaztunok eulietako Rngo proteinaren 2 proteina homologo ditugu: DDI1 eta DDI2 (ingelesezko DNA damageinducible protein 1 homologue 1 eta 2 , hurrenez hurren). UBE3A giza zeluletan DDI1 edota DDI2 ubikuitinatzeko gai denetz frogatzeko, SH-SY5Y neuroblastoma zelulak erabili ditugu. Hasteko, zeluletan honako proteina hauek gainadierazi ditugu: Flag etiketadun ubikuitina, UBE3A (funtzionala [wt] edo ez-funtzionala [mut]) eta GFP proteina fluoreszentearekin markatutako DDI1 edo DDI2. Ondoren, GFPdun proteinak (DDI1 edo DDI2) isolatu, eta, Western plapaketaren bidez, haien ubikuitinazio-maila detektatu dugu (5A irudia).

$\mathbf{A}$

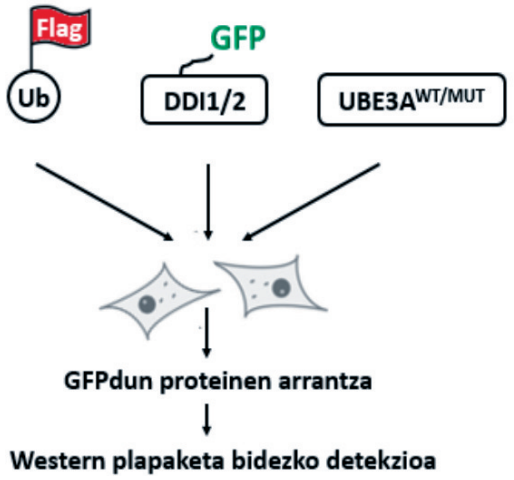

B

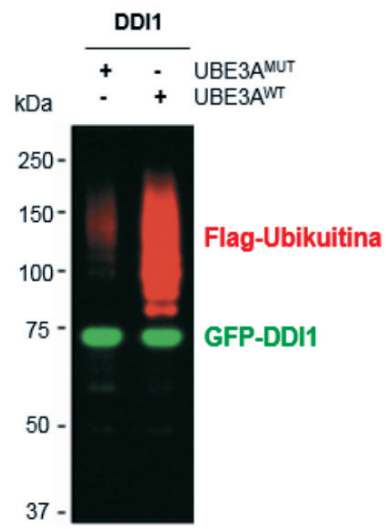

5. irudia. UBE3Aren substratuen balioztatzea giza zeluletan. (A) Rngo-ren giza homologoak, hots, DDI1 eta DDI2, UBE3Aren substratuak direnetz frogatzeko erabilitako estrategia. (B) DDI1-en ubikuitinazio-maila ia antzematezina da UBE3A ez-funtzionalaren presentzian (UBE3A $\left.{ }^{\mathrm{MUT}}\right)$. Aitzitik, UBE3A funtzionalarekin (UBE3A ${ }^{\mathrm{WT}}$ ) batera gainadieraztean, DDI1-en ubikuitinazioa erruz induzitzen da.

GFP-DDI2 funtzionala zein ez-funtzionala den UBE3Arekin gainadieraztean, beraren ubikuitinazio-maila bertsua dela ikusi genuen (ez da emai- 
tza erakusten). Ondorioz, emaitza horren arabera, DDI2 ez da UBE3Aren substratua. Bestetik, DDI1-en ubikuitinazio-maila antzemanezina da UBE3A ez-funtzionala gainadierazten duten zeluletan. Aitzitik, UBE3A funtzionala gainadierazten duten zeluletan, DDI1-en ubikuitinazio-maila oso nabarmena da; horrenbestez, giza DDI1 UBE3Aren substratua badela frogatzen da (5B irudia) [16].

\section{ONDORIOAK}

Angelman sindromea pairatzen dutenek UBE3A entzimaren gabezia daukate neuronetan. Hori dela eta, UBE3Aren itu-proteinen ubikuitinaziomaila ez da egokia, eta horrek ondorio latzak eragiten ditu. Momentuz, ez dira ezagutzen zein diren UBE3Aren substratu horiek giza garunean. Eta, gure ustez, horiek identifikatzea ezagutzea ezinbestekoa da gaitzarekin erlazionatutako sintomak arintzen lagunduko duten farmako berriak diseinatu ahal izateko. Xede horretan, gure ikerketak eulietan azaleratutako emaitzak interesgarriak direlakoan gaude.

Antzeko ikerketa giza laginekin egitea egokiagoa litzatekeela argi dago. Baina giza laginekin lan egiteak dituen mugak direla eta, lehen saioak euliekin egitea erabaki genuen. Zehazki, UBE3A gainadierazten duten eta gainadierazten ez duten BioUb eulietatik abiatuta, eta, gure lantaldean garatutako bioUB teknikari esker, ubikuitinatutako proteinak isolatu eta MSren bidez aztertu ditugu. Identifikatu eta kuantifikatutako ehunka proteinetatik, 79 proteinak betetzen dituzte UBE3Aren substratu izateko gutxieneko baldintzak. Horietako askok (besteak beste, Western plapaketaren bidez egiaztatu dugun Rngo proteinak) proteinen homeostasian parte hartzen dute. Emaitza horretatik abiatuz, Rngo-ren giza homologoa den DDI1 UBE3Aren substratua dela ere frogatu dugu. Gure emaitzek ikuspegi berri bat ireki dute AS arloan, argi utzi dutelako UBE3A entzimak zelularen homeostasia kontrolatzen duela. Hurrengo urratsa substratu posible horiek balioztatzen jarraitzea izango da. Horretaz gain, antzeko esperimentua saguekin egiteko asmoa ere badaukagu.

\section{ESKER ONAK}

Lan honetan egindako MS bidezko analisiak UPV/EHUko Proteomika Zerbitzuan (SGIker) egin dira. Lan hau March of Dimes-en, Instituto de Salud Carlos IIIren eta Espainiako MINECOren finantzazioei esker burutu da. 
Juanma Ramirez, Benoit Lectez, Nerea Osinalde, Nagore Elu, Ugo Mayor

\section{BIBLIOGRAFIA}

[1] BUITING K, WILLIAMS C, eta HORSTHEMKE B. 2016. «Angelman syndrome - insights into a rare neurogenetic disorder». Nature Reviews Neurology, 12, 584-593.

[2] MATSUURA T, SUTCLIFFE JS, FANG P, GALJAARD R-J, JIANG Y, BENTON CS, ROMMENS JM eta BEAUDET AL. 1997. «De novo truncating mutations in E6-AP ubiquitin-protein ligase gene (UBE3A) in Angelman syndrome». Nature Genetics, 15, 74-77.

[3] KISHINO T, LALANDE M eta WAGSTAFF J. 1997. «UBE3A/E6-AP mutations cause Angelman syndrome». Nature Genetics, 15, 70-73.

[4] TAI H-C eta SCHUMAN EM. 2008. «Ubiquitin, the proteasome and protein degradation in neuronal function and dysfunction». Nature Reviews Neuroscience, 9, 826-838.

[5] GATZA ML, DAYARAM T eta MARRIOTT SJ. 2007. «Ubiquitination of HTLV-I Tax in response to DNA damage regulates nuclear complex formation and nuclear export». Retrovirology, 14, 95-107.

[6] MURATA T eta SHIMOTOHNO K. 2006. «Ubiquitination and proteasomedependent degradation of human eukaryotic translation initiation factor 4E». J Biol Chem, 28, 20788-20800.

[7] BARBASH O, EGAN E, PONTANO LL, KOSAK J eta ALAN D. 2009. «Lysine 269 is essential for cyclin D1 ubiquitylation by the SCFFbx $4 / \alpha \mathrm{B}$ crystallin ligase and subsequent proteasome-dependent degradation». Oncogene, 28, 4317-4325.

[8] BATONNET S, LEIBOVITCH MP, TINTIGNAC L eta LEIBOVITCH SA. 2004. «Critical Role for Lysine 133 in the Nuclear Ubiquitin-mediated Degradation of MyoD». J Biol Chem, 13, 5413-5420.

[9] LIU Y eta DENG J. 2019. «Ubiquitination-deubiquitination in the Hippo signaling pathway». Oncology Reports, 41, 1455-1475.

[10] WU Y, KANG J, ZHANG L, LIANG Z, TANG X, YAN Y, QIAN H, ZHANG X, XU W eta MAO F. 2018. «Ubiquitination regulation of inflam-

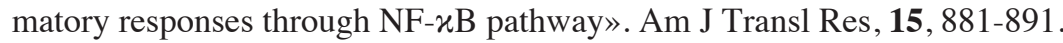

[11] HU H eta SUN S-C. 2016. «Ubiquitin signaling in immune responses». Cell Research, 26, 457-483.

[12] NA CH, JONES DR, YANG Y, WANG X, XU Y eta PENG J. 2012. «Synaptic protein ubiquitination in rat brain revealed by antibody-based ubiquitome analysis». J Proteome Res, 11, 4722-4732.

[13] XU G, PAIGE J eta JAFFREY S. 2010. «Global analysis of lysine ubiquitination by ubiquitin remnant immunoaffinity profiling». Nature Biotechnology, 28, 868-873.

[14] KIM W, BENNETT EJ, HUTTLIN EL, GUO A, LI J, POSSEMATO A, SOWA ME, RAD R, RUSH J, COMB MJ, HARPER JW eta GYGI SP. 2011. «Systematic and Quantitative Assessment of the Ubiquitin-Modified Proteome». Molecular Cell, 44, 325-340. 
[15] FRANCO M, SEYFRIEND NT, BRAND AH, PENG J eta MAYOR U. 2011. «A Novel Strategy to Isolate Ubiquitin Conjugates Reveals Wide Role for Ubiquitination during Neural Development». Mol Cell Proteomics, 10, $1-15$.

[16] RAMIREZ J, LECTEZ B, OSINALDE N, SIVÁ M, ELU N, ALORIA K, PROCHAZKOVA M, PEREZ C, MARTINEZ-HERNANDEZ J, BARRIO R, SASKOVA KG, ARIZMENDI JM eta MAYOR U. 2011. «Quantitative proteomics reveals neuronal ubiquitination of Rngo/Ddi1 and several proteasomal subunits by Ube3a, accounting for the complexity of Angelman syndrome». Hum Mol Genet., 27, 1955-1971.

[17] OSINALDE N, SÁNCHEZ-QUILES V, BLAGOEV B eta KRATCHMAROVA I. 2017. «Data on interleukin (IL)-2- and IL-15-dependent changes in IL-2R $\beta$ and IL-2R $\gamma$ complexes». Data in Brief., 11, 499-506.

[18] WONG JWH eta CAGNEY G. 2010. «An Overview of Label-Free Quantitation Methods in Proteomics by Mass Spectrometry». Methods in Molecular Biology, 273-283

[19] MIZUSHIMA N, YOSHIMORI T eta OHSUMI Y. 2011. «The role of Atg proteins in autophagosome formation». Annu Rev Cell Dev Biol., 27, 107132.

[20] DEVORKIN L eta GORSKI SM. 2014. «Monitoring autophagic flux using Ref(2)P, the Drosophila p62 ortholog». Cold Spring Harb Protoc., 9, 959966.

[21] FINLEY D, CHEN X eta WALTERS KJ. 2014. «Gates, channels, and switches: elements of the proteasome machine». Trends Biochem Sci, 41, 77-93.

[22] ZHANG Z, KRUTCHNSKY A, ENDICOTT S, REALINI C, RECHSTEINER M eta STANDING. 1999. «Proteasome Activator 11S REG or PA28: Recombinant REG $\alpha /$ REG $\beta$ Hetero-oligomers Are Heptamers 1». Biochemistry, 38, 5651-5658.

[23] HONEMANN-CAPITO M, VON STEIN W eta WODARZ A. 2011. «Loss of the extraproteasomal ubiquitin receptor Rings lost impairs ring canal growth in Drosophila oogenesis». J Cell Biol, 193, 71-80.

[24] LIPINSZKI Z, KISS P, PÁL M, DEÁK P, SZABÓ Á, HUNYADI-GULYAS E, KLEMENT E, MEDZIHRADSZKY KF eta UDVARDY A. 2009. «Developmental-stage-specific regulation of the polyubiquitin receptors in Drosophila melanogaster». J Cell Sci. 22, 3083-3092.

[25] LEE SY, RAMIREZ J, FRANCO M, LECTEZ B, GONZALEZ M, BARRIO R eta MAYOR U. 2014. «Ube3a, the E3 ubiquitin ligase causing Angelman syndrome and linked to autism, regulates protein homeostasis through the proteasomal shuttle Rpn10». Cell Mol Life Sci, 14, 2747-2758. 